Revue des patrimoines

$28 \mid 2016$

Le moulage. Pratiques historiques et regards contemporains

\title{
Un ministère en quête d'identité ? Une histoire du ministère de la Défense par ses bâtiments, des années trente à nos jours
}

\section{Emmanuel Pénicaut}

\section{OpenEdition}

Journals

Édition électronique

URL : http://journals.openedition.org/insitu/15865

DOI : 10.4000/insitu. 15865

ISSN : 1630-7305

Éditeur

Ministère de la culture

Référence électronique

Emmanuel Pénicaut, « Un ministère en quête d'identité ? Une histoire du ministère de la Défense par ses bâtiments, des années trente à nos jours », In Situ [En ligne], 28 | 2016, mis en ligne le 27 avril 2018, consulté le 30 avril 2019. URL : http://journals.openedition.org/insitu/15865 ; DOI : 10.4000/ insitu. 15865

Ce document a été généré automatiquement le 30 avril 2019.

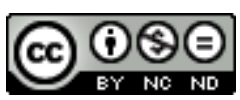

In Situ Revues des patrimoines est mis à disposition selon les termes de la licence Creative Commons Attribution - Pas d'Utilisation Commerciale - Pas de Modification 4.0 International. 


\section{Un ministère en quête d'identité ? Une histoire du ministère de la Défense par ses bâtiments, des années trente à nos jours}

\section{Emmanuel Pénicaut}

\section{Voir :}

2 Emmanuel Pénicaut, « Un ministère en quête d'identité ? Une histoire du ministère de la Défense par ses bâtiments, des années trente à nos jours ", In Situ [En ligne], 34 | 2018, mis en ligne le 27 avril 2018, consulté le 27 avril 2018. URL : http://journals.openedition.org/ insitu/15864

\section{AUTEUR}

\section{EMMANUEL PÉNICAUT}

Adjoint au directeur de la médiathèque de l'Architecture et du Patrimoine emmanuel.penicaut@culture.gouv.fr 